\title{
Collar Rot of Peanut Caused by Lasiodiplodia theobromae
}

\author{
P. M. Phipps, Professor of Plant Pathology, Virginia Tech, and D. M. Porter, Research Plant Pathologist (Ret.), \\ USDA-ARS, Tidewater Agricultural Research and Extension Center, Suffolk, VA 23437
}

\begin{abstract}
Phipps, P. M., and Porter, D. M. 1998. Collar rot of peanut caused by Lasiodiplodia theobromae. Plant Dis. 82:1205-1209.

In August and September of 1993, a collar rot disease of peanut was observed in several fields in Virginia and North Carolina. Only a few scattered plants exhibited symptoms and signs of the disease in Southampton County and Suffolk, Virginia, and Northampton County, North Carolina. The disease was severe at two farm sites in Dinwiddie County, Virginia where the affected areas exceeded 0.4 ha in size. Numerous plants were either chlorotic, wilted, or dead. Symptomatic plants exhibited blackened stem cankers and pods. Diseased stems and tap roots were easily shredded to reveal slate-gray to black internal tissues. Black, erumpent pycnidia were observed on stem lesions at the soil surface. Immature conidia were single-celled and hyaline. Mature conidia were two-celled and dark brown. Morphological features of the fungus on diseased plants and potato dextrose agar were consistent with descriptions of Lasiodiplodia theobromae (Diplodia gossypina). The fungus was isolated from discolored seed and asymptomatic seed from fields having plants which exhibited severe symptoms. Seed treatment with captan $1.125 \mathrm{~g}+$ pentachloronitrobenzene $0.375 \mathrm{~g}+$ carboxin $0.25 \mathrm{~g}$ a.i. $/ \mathrm{kg}$ reduced recovery of the fungus from seed, but did not eradicate the pathogen. This treatment on naturally infested seed provided significant early-season disease suppression and improved yield significantly in 1994. Season-long disease suppression and a significant yield increase were obtained in plots planted to fungicide-treated, commercial seed from non-infested fields. At-plant and mid-season applications of fungicides in 1994 and 1995 did not improve disease suppression over that of fungicide-treated, commercial seed. Overall, Virginia-type cultivars of peanut were more susceptible to collar rot than runner-type cultivars. Among the Virginia-type cultivars, NC-V 11 exhibited moderate susceptibility and the 79-X breeding line from Florida exhibited resistance. Georgia Browne and Southern Runner were the most resistant of the runner-type cultivars.
\end{abstract}

Additional keywords: chemical control, cultivar susceptibility, pathogenicity

Collar rot of peanut (Arachis hypogaea L.), caused by Lasiodiplodia theobromae (Pat.) Griffon and Maubl. (Diplodia gossypina Cooke), occurs sporadically in peanut seed (10). Collar rot was first reported in the United States in 1932 (9) and causes disease in immature and mature plants (13,14). Jacoway and Owen (6) reported that incidence of collar rot was widespread and approached $30 \%$ in Georgia and Florida in 1951. In North Carolina, collar rot has been observed since 1947, when losses in some areas reached $25 \%$ (8). Although the disease has not been reported to cause economic losses in the United States during the past 25 years, single diseased plants have been observed occasionally in North Carolina and Virginia.

L. theobromae is thought to be a weak parasite and is often characterized as a

Corresponding author: P. M. Phipps
E-mail: pmphipps@ vt.edu

Accepted for publication 13 July 1998.

Publication no. D-1998-0821-01R

(C) 1998 The American Phytopathological Society wound parasite or secondary pathogen of peanut $(1,13)$. Collar rot of peanut has been associated with bacterial wilt (9), wounding (6), heat canker (1), and heat predisposition $(7,8)$. McGuire and Cooper (8) demonstrated the pathogenicity of $L$. theobromae on peanut, but noted that infection rarely occurs in the absence of predisposition by heat injury or wounding. Subsequent studies under greenhouse conditions have indicated that infection is possible without wounding $(5,11)$.

In 1993, collar rot was observed in several peanut fields in Virginia and North Carolina. At field sites in Southampton County and Suffolk, Virginia, and Northampton County, North Carolina, only a few diseased plants were noted. However, at two farm sites in Dinwiddie County, Virginia, the disease was severe, with affected areas exceeding 0.4 ha in size (12). In these areas, plants were either wilted or dead and pod losses were estimated at $75 \%$.

This report describes laboratory and field investigations of the disease and causal organism in 1993, 1994, and 1995. Objectives were to (i) isolate and compare the cultural characteristics of $L$. theobromae from different locations, (ii) compare the virulence of isolates, (iii) determine the incidence of $L$. theobromae in peanut seed, (iv) evaluate seed and field applications of fungicides for disease control, and (v) compare the relative susceptibility of peanut cultivars.

\section{MATERIALS AND METHODS}

Diseased stems, tap roots, and pods were obtained from eight farm sites in Virginia and North Carolina. Discolored pods also were obtained from two farm sites in Texas where above-ground symptoms of the disease were not apparent. Samples were surface-disinfested in $0.5 \% \mathrm{NaOCl}$ for 3 min., placed on potato dextrose agar (PDA) in $9-\mathrm{cm}$ petri plates, and incubated at $30^{\circ} \mathrm{C}$ for 7 days. Stock cultures of $L$. theobromae were obtained using the hyphal tip transfer procedure, and maintained in tube slants of PDA at $10^{\circ} \mathrm{C}$. Mycelial growth studies were initiated by culturing the fungus on PDA in plates. After mycelium reached the outer edges of a dish, 5mm-diameter cores of mycelium with agar were removed and placed (inverted) in the center of plates containing fresh PDA. Radial growth in darkness at $30^{\circ} \mathrm{C}$ was measured daily. Five replications of plates with each isolate were used, and the trial was repeated.

Virulence tests were conducted with isolates of $L$. theobromae from six locations. Isolates were grown on PDA in darkness at $30^{\circ} \mathrm{C}$. Lateral branches of field-grown peanut (cv. VA-C 92R) were collected and rinsed in distilled water. A single internode segment was selected from the middle of each branch, trimmed to a $10-\mathrm{cm}$ length, and placed in plastic boxes ( 25 by 12 by $4 \mathrm{~cm}$ ) containing moist paper towels and two sterilized strips of wood. A total of 10 internode segments were evenly spaced and supported at each end by the wood strips in each box. A $1-\mathrm{cm}$ section of the surface in the center of each branch piece was then scraped (wounded) with a sterilized spatula and inoculated with an inverted 5-mm-diameter disk of mycelium and agar from a PDA culture. After branch inoculations, the boxes were closed and placed in an incubator at $30^{\circ} \mathrm{C}$. Lesion lengths were measured after 4 days. Five replications (boxes) of 10 stems per isolate were used in four separate trials.

Seed infestation studies were conducted with seed of NC 9 peanut from fields exhibiting moderate (approximately 20\%) and severe $(>75 \%)$ disease incidence in Dinwiddie County, Virginia. Peanuts were inverted, dried from 4 to 6 days in wind- 
rows, picked mechanically, and dried further using recommended procedures to approximately $10 \%$ moisture (wt/wt). Before shelling, foreign material and loose shelled kernels were removed from each seed lot. Pods were shelled with a small peanut sheller and sized over a 6.4- by 25.4-mm screen. Seed with visible damage

The incidence of $L$. theobromae in seed was determined through biopsy of seed (four/plate) on PDA in 9-cm-diameter dishes. Seed were surface disinfested for 3 min. in $0.5 \% \mathrm{NaOCl}$ and blotted dry on sterile filter paper. After incubation at $30^{\circ} \mathrm{C}$ for 7 days, cultures were observed for the presence of mycelium and pycnidia characteristic of $L$. theobromae. If the identity of an isolate was questionable, subcultures were made on PDA for further observation. In additional studies, the testa of seed was removed before biopsy on PDA. Seed were soaked in distilled water for $30 \mathrm{~min}$ and blotted dry with filter paper, after which the shriveled testa were removed with sterile forceps. In other tests, the seed with and without testa were cut latitudinally into two equal parts. Seed were removed by hand from each seed lot.

were then treated in $0.5 \% \mathrm{NaOCl}$ and biopsied by placing whole and freshly cut seed on PDA.

Captan $1.125 \mathrm{~g}+$ pentachloronitrobenzene (PCNB) $0.375 \mathrm{~g}+$ carboxin $0.25 \mathrm{~g}$ a.i./kg of seed was used in tests to determine the effects of seed treatment on survival of $L$. theobromae. This treatment is marketed as Vitavax PC (45\% captan, 15\% PCNB, $10 \%$ carboxin) and formulated for dry application at $2.5 \mathrm{~g} / \mathrm{kg}$ of seed in the Virginia and North Carolina region. The seed treatment was applied uniformly over the surface of seed by tumbling for $3 \mathrm{~min}$ in a Gustafson Lab Treater (Gustafson Inc., Plano, TX). Seed were rinsed in sterile distilled water to remove surface adhering fungicide 2 weeks after treatment. Whole seed and latitudinally cut seed, with and without testa, were then biopsied on PDA following a 3-min treatment in $0.5 \%$ $\mathrm{NaOCl}$.

Field sites in Dinwiddie county with severe symptoms of collar rot in 1993 were selected for evaluations of cultivars and fungicide treatments in 1994 and 1995. The site in 1995 was cropped to tobacco in 1994. The utility of fungicide treatments

Table 1. Location, incidence of collar rot on peanut, and cultural characteristics of isolates of Lasiodiplodia theobromae from Virginia, North Carolina, and Texas

\begin{tabular}{lccc}
\hline & & \multicolumn{2}{c}{ Mycelial growth $^{\mathbf{y}}$} \\
\cline { 3 - 4 } Origin of isolate & Disease incidence $^{\mathbf{z}}$ & Rate $^{(\mathbf{m m} / \mathbf{d a y})}$ & Appearance $^{\text {nnyyy}}$ \\
\hline Dinwiddie County, VA & $>75 \%$ & 14.2 & Appressed \\
Dinwiddie County, VA & $<20 \%$ & 14.4 & Appressed \\
Dinwiddie County, VA & $>50 \%$ & 14.0 & Appressed \\
Dinwiddie County, VA & $<25 \%$ & 13.8 & Appressed \\
Suffolk, VA & $<1 \%$ & 14.2 & Aerial \\
Suffolk, VA & $<1 \%$ & 13.8 & Aerial \\
Southampton County, VA & $<1 \%$ & 14.4 & Aerial \\
Northampton, NC & $<1 \%$ & 14.4 & Aerial \\
Frio County, TX & None & 14.2 & Aerial \\
Frio County, TX & None & 14.0 & Aerial \\
Yoakum, TX & None & 14.0 & Aerial \\
Yoakum, TX & None & 14.4 & Aerial \\
\hline
\end{tabular}

${ }^{y}$ Mycelial growth characteristics were assessed on potato dextrose agar. Growth rates were measured on cultures incubated in the dark at $30^{\circ} \mathrm{C}$ over a period of 3 days. Rates were not significantly different $(P=0.05)$ for isolates in two tests with five replications per isolate.

${ }^{\mathrm{z}}$ Disease incidence was estimated from field observations of plants with symptoms of collar rot prior to harvest in 1993.

Table 2. Lesion development on detached stems of VA-C 92R peanut following inoculation with isolates of Lasiodiplodia theobromae

\begin{tabular}{|c|c|c|c|c|c|}
\hline \multirow[b]{2}{*}{ Origin of isolate } & \multirow[b]{2}{*}{ Disease incidence ${ }^{\mathrm{z}}$} & \multicolumn{4}{|c|}{ Mean lesion length $(\mathrm{mm})^{y}$} \\
\hline & & Test 1 & Test 2 & Test 3 & Test 4 \\
\hline Dinwiddie County, VA & $>75 \%$ & $6.0 \mathrm{a}$ & $5.1 \mathrm{a}$ & $5.2 \mathrm{~b}$ & $6.2 \mathrm{~b}$ \\
\hline Dinwiddie County, VA & $>75 \%$ & $7.0 \mathrm{a}$ & $3.5 \mathrm{~b}$ & $6.8 \mathrm{a}$ & $6.1 \mathrm{~b}$ \\
\hline Dinwiddie County, VA & $>75 \%$ & $6.1 \mathrm{a}$ & $5.8 \mathrm{a}$ & $7.3 \mathrm{a}$ & $9.0 \mathrm{a}$ \\
\hline Suffolk, VA & $<1 \%$ & $2.1 \mathrm{~b}$ & $0.3 \mathrm{c}$ & $0.4 \mathrm{c}$ & $0.5 \mathrm{~d}$ \\
\hline Northampton County, NC & $<1 \%$ & $\ldots$ & $0.5 \mathrm{c}$ & $1.0 \mathrm{c}$ & $2.5 \mathrm{c}$ \\
\hline Frio County, TX & None & $1.1 \mathrm{~b}$ & $0.1 \mathrm{c}$ & $0.9 \mathrm{c}$ & $0.6 \mathrm{~d}$ \\
\hline Yoakum, TX & None & $1.9 \mathrm{~b}$ & $0.0 \mathrm{c}$ & $0.3 \mathrm{c}$ & $0.0 \mathrm{~d}$ \\
\hline
\end{tabular}

${ }^{\mathrm{y}}$ Data are mean lesion length after 5 days of incubation at $30^{\circ} \mathrm{C}$. Each test included 10 detached stems per replicate and five replications per isolate. Branch segments were inoculated by placing an agar disk with actively growing mycelium of the fungus on the internode. Means in columns followed with same letter are not significantly different according to Duncan's multiple range test $(P=$ $0.05)$.

${ }^{\mathrm{z}}$ Disease incidence was estimated from field observations of plants with symptoms of collar rot in 1993. for control of collar rot was determined with seed of NC 9 peanut from a field that exhibited severe collar rot symptoms in 1993 and commercial seed from an area where the disease was not detected. The commercial seed of $\mathrm{NC} 9$ was used to evaluate field applications of fungicides. Seed from the infested field were planted in the same trial with and without seed treatment fungicides (captan $1.125 \mathrm{~g}+$ PCNB $0.375 \mathrm{~g}+$ carboxin $0.25 \mathrm{~g}$ a.i. $/ \mathrm{kg}$ seed). The seed treatment was applied with the Gustafson Lab Treater as defined previously. Field plots consisted of two 12.2$\mathrm{m}$ rows in 1994 and two 10-m rows in 1995. Row spacing was $0.9 \mathrm{~m}$, and two buffer rows separated adjacent plots in 1995. Entries in all field trials were replicated in four randomized complete blocks.

Soil-applied fungicide treatments were tested only in plots planted to commercial seed. Planting-time applications of fungicides in 1994 were applied in a 20-cm band over each row and soil incorporated with a rolling cultivator. Subsequent applications were applied in a $30-\mathrm{cm}$ band at 60 days after planting (DAP) and a 46-cm band over rows at 90 DAP. Granular PCNB (Terraclor 10G), and PCNB + metalaxyl (Ridomil PC 11G) were delivered with a Noble applicator. Sprays of fluazinam (Fluazinam 500) were applied with one 8010LP nozzle delivering 374 liters/ha.

In 1995, preplant treatments of metam sodium (Vapam $32.7 \%$ ) were applied in a $46-\mathrm{cm}$ band with one 8004E nozzle over each row for delivery of $36 \mathrm{~kg}$ a.i./ha, and one 8008LP nozzle over each row for delivery of $72 \mathrm{~kg}$ a.i./ha. Each treatment was soil incorporated to a depth of $10 \mathrm{~cm}$ with a Ferguson Tilrovator (Ferguson Mfg. Co., Suffolk, Va.). All other treatments were applied in a $30-\mathrm{cm}$ band over rows at planting and 60 DAP. At-planting treatments of granular fungicides were applied with the same equipment and soil incorporated as in 1994. Fungicide sprays were applied with one 8004E nozzle per row delivering 96 liters/ha and soil incorporated at planting with a rolling cultivator. The 60 DAP sprays were applied with one 8010LP nozzle per row, delivering 374 liters/ha.

To assess the susceptibility of peanut to the disease in 1994 and 1995, 10 commercial cultivars and 2 breeding lines were used. Plots consisted of two 12.2-m rows in 1994 and two 10-m rows in 1995. Rows were spaced $0.9 \mathrm{~m}$ apart, and entries in each trial were replicated in four randomized complete blocks.

Standard practices for peanut production were followed throughout each growing season (15). Chlorothalonil at $1.26 \mathrm{~kg} / \mathrm{ha}$ was applied four times in both years according to the Virginia peanut leaf spot advisory program (2). No additional fungicides were used. Collar rot was the only disease observed on above- and belowground parts of plants each year. Numbers 
of plants with symptoms and signs of collar rot in each plot were recorded twice during each growing season and at harvest. Yields were determined by digging (19 Oct 1994 and 1995), combining (27 Oct 1994 and 25 Oct 1995), drying (approximately 8 to $10 \% \mathrm{w} / \mathrm{twt}$ ), and weighing peanuts from each plot.

\section{RESULTS AND DISCUSSION}

L. theobromae was readily isolated from peanut stems, pod shells, and seed from fields exhibiting typical collar rot symptoms in Virginia and Northampton County, North Carolina. Asymptomatic shell pieces and seed from two locations in Texas also yielded isolates of $L$. theobromae. Other research has shown that $L$. theobromae can be isolated from both unblemished and blemished peanut seed $(3,7,9)$.

The mycelial growth rate of 12 isolates of $L$. theobromae on PDA averaged 13.8 to $14.4 \mathrm{~mm}$ per day when incubated in darkness at $30^{\circ} \mathrm{C}$ (Table 1). Included were four isolates from peanut fields with severe disease in Dinwiddie County, and four isolates from other fields in the Virginia and North Carolina production area, where only a few diseased plants were observed. An additional four isolates were obtained from asymptomatic peanuts in pods from Frio County and Yoakum, Texas. Differences in mycelial growth rates between the 12 isolates of L. theobromae were not significant in two replicated tests, but distinct morphological differences were noted. Isolates from the four locations in Dinwiddie County exhibited appressed mycelial growth on PDA, while isolates from other locations exhibited cottony, aerial growth.

Black, erumpent pycnidia with a prominent ostiole were frequently observed on stems near the crown of symptomatic plants in Dinwiddie County. Two types of pycnidiospores were produced by all isolates: single-celled hyaline (immature) and 2-celled, dark brown spores (mature). Mature pycnidiospores measured 17 to $34 \times$ 10 to $18 \mu \mathrm{m}$. Overall, the causal fungus and disease symptoms on peanut appeared to be the same as that reported in 1951 in the Georgia to Florida area (6).

The aggressiveness of seven isolates in colonizing the internode of inoculated peanut branches appeared to be related to disease incidence in fields from which they originated (Table 2). The most aggressive isolates were from locations with the greatest incidence of collar rot. Isolates from fields exhibiting little or no disease caused lesions that were consistently smaller than lesions caused by isolates from heavily diseased fields.

$L$. theobromae was isolated with ease from dried peanut seed obtained from fields exhibiting symptoms of collar rot in Dinwiddie County, Virginia (Table 3). The isolation frequency was greatest from seed collected where disease incidence was high. Storage of seed following pod shelling had no apparent effect on the isolation frequency of $L$. theobromae; recovery rates were similar in early (December and January) and late (February and March) assays. Treatment of seed with captan $1.125 \mathrm{~g} \mathrm{+}$ PCNB $0.375 \mathrm{~g}+$ carboxin $0.25 \mathrm{~g}$ a.i. $/ \mathrm{kg}$ reduced the isolation frequency of $L$. theobromae. An additional reduction in recovery of the fungus was suggested from storage of treated seed for periods of up to 2 months.

L. theobromae was isolated from whole and cut seed that were surface-disinfested in $0.5 \% \mathrm{NaOCl}$ (Table 3). Removal of the seed testa, cutting seed, or both factors appeared to have little or no effect on recovery of the fungus. In all but one instance, the isolation frequency was significantly lower from fungicide-treated seed compared to non-treated seed. Although the seed testa may provide some protection from colonization by $L$. theobromae, it did

not prevent the fungus from invading the underlying tissue.

The importance of seed transmission of the organism was supported further by results of the field trial in 1994. Disease incidence on 11 July was high in plots planted to farm seed without the standard seed treatment fungicide (Table 4). These seed were harvested from a field with moderate to severe damage by collar rot in 1993. A significant reduction in disease incidence was observed on 11 July in plots planted with fungicide-treated seed. Disease counts on 2 August also reflected the benefit of seed treatment fungicide, but numbers were much lower than counts on 11 July due to the rapid decay and disappearance of dead seedlings. Counts on 4 October, just prior to harvest, reflected a resurgence in disease to high levels in plots planted to naturally infested farm seed with and without seed treatment. Yield data exhibited a step-wise increase with appli-

Table 3. Factors affecting the isolation frequency of Lasiodiplodia theobromae from peanut

\begin{tabular}{lcc}
\hline & \multicolumn{2}{c}{${\text { Isolation frequency }(\%)^{\mathbf{x}}}$} \\
\cline { 2 - 3 } Seed sample and origin & Untreated seed $^{\mathbf{y}}$ & Treated seed $^{\mathbf{z}}$ \\
\hline Whole seed, Dinwiddie-1 (test A) & $13.3 \mathrm{a}$ & $10.3 \mathrm{~b}$ \\
Whole seed, Dinwiddie-1 (test B) & $15.2 \mathrm{a}$ & $7.8 \mathrm{~b}$ \\
Whole seed, Suffolk (test A) & $1.6 \mathrm{a}$ & $1.3 \mathrm{a}$ \\
Whole seed, Suffolk (test B) & $2.4 \mathrm{a}$ & $0.8 \mathrm{~b}$ \\
Whole seed with testa, Dinwiddie-2 & $7.8 \mathrm{a}$ & $4.2 \mathrm{~b}$ \\
Whole seed without testa, Dinwiddie-2 & $5.1 \mathrm{a}$ & $2.8 \mathrm{~b}$ \\
Cut seed with testa, Dinwiddie-2 & $8.6 \mathrm{a}$ & $3.2 \mathrm{~b}$ \\
Cut seed without testa, Dinwiddie-2 & $8.9 \mathrm{a}$ & $4.4 \mathrm{~b}$ \\
\hline
\end{tabular}

$\mathrm{x}$ Biopsy assays used a mixture of extra large, medium, and number one peanuts with non-discolored testa. Means in rows followed by the same letter are not significantly different according to Duncan's multiple range test $(P=0.05)$.

y Percentage of 100 seed (five replications) yielding L. theobromae in biopsy assays on potato dextrose agar. Seed from Dinwiddie-1, Dinwiddie-2, and Suffolk were harvested from peanut fields exhibiting ca. 75,20 , and $1 \%$ incidence of collar rot, respectively. Testa were removed by soaking seed for $30 \mathrm{~min}$ in sterile distilled water. Cut seed were divided latitudinally. Tests A and B were initiated in December and February, respectively.

z Treated with captan $1.125 \mathrm{~g}+$ pentachloronitrobenzene $0.375 \mathrm{~g}+$ carboxin $0.25 \mathrm{~g}$ a.i. $/ \mathrm{kg}$ seed.

Table 4. Evaluation of seed- and soil-applied fungicides for control of collar rot of peanut in a naturally infested field in 1994

\begin{tabular}{|c|c|c|c|c|}
\hline \multirow[b]{2}{*}{ Seed source and treatment ${ }^{w}$} & \multicolumn{4}{|c|}{ Collar rot $^{v}$} \\
\hline & Jul 11 & Aug 2 & Oct 4 & Yield $^{\mathrm{x}}$ \\
\hline \multicolumn{5}{|l|}{ Naturally infested seed } \\
\hline Untreated & $45.7 \mathrm{a}^{\mathrm{y}}$ & $11.7 \mathrm{a}$ & $45.3 \mathrm{a}$ & $2,201 \mathrm{~d}$ \\
\hline Treated $^{\mathrm{z}}$ & $13.0 \mathrm{~b}$ & $2.0 \mathrm{~b}$ & $46.0 \mathrm{a}$ & $2,859 \mathrm{~b}-\mathrm{d}$ \\
\hline \multicolumn{5}{|l|}{ Commercial seed ${ }^{\mathrm{z}}$} \\
\hline No soil fungicide & $5.0 \mathrm{~b}$ & $2.3 \mathrm{~b}$ & $27.3 \mathrm{~b}$ & $3,413 \mathrm{a}-\mathrm{c}$ \\
\hline PCNB $2.8 \mathrm{~kg}$ a.i./ha (AP) & $6.8 \mathrm{~b}$ & $2.8 \mathrm{~b}$ & $34.8 \mathrm{ab}$ & $3,462 \mathrm{a}-\mathrm{c}$ \\
\hline PCNB $2.8 \mathrm{~kg}$ + metalaxyl $0.2 \mathrm{~kg}$ a.i./ha (AP) & $6.0 \mathrm{~b}$ & $2.3 \mathrm{~b}$ & $28.0 \mathrm{~b}$ & $3,635 \mathrm{a}$ \\
\hline PCNB $2.8 \mathrm{~kg}$ a.i./ha (60 DAP) & $8.8 \mathrm{~b}$ & $4.5 \mathrm{~b}$ & $39.0 \mathrm{a}$ & $2,785 \mathrm{~cd}$ \\
\hline PCNB $2.8 \mathrm{~kg}$ + metalaxyl $0.2 \mathrm{~kg}$ a.i./ha (60 DAP) & $5.3 \mathrm{~b}$ & $4.8 \mathrm{~b}$ & $32.3 \mathrm{ab}$ & $3,105 \mathrm{a}-\mathrm{c}$ \\
\hline Fluazinam $1.12 \mathrm{~kg}$ a.i./ha $(60 \& 95 \mathrm{DAP})$ & $5.5 \mathrm{~b}$ & $1.5 \mathrm{~b}$ & $25.8 \mathrm{~b}$ & $3,573 \mathrm{ab}$ \\
\hline
\end{tabular}

${ }^{v}$ Counts of symptomatic and dead plants.

${ }^{\text {w}}$ Naturally infested seed (cv. NC 9) were obtained from Dinwiddie County, Virginia, where collar rot was observed in 1993. Commercial seed (cv. NC 9) were produced in fields believed to be free of collar rot. Soil fungicide was applied as follows: $\mathrm{AP}=$ at planting (16 May); $60 \mathrm{DAP}=60$ days after planting (15 Jul); 95 DAP $=95$ days after planting (19 Aug).

${ }^{x}$ Yields are weight of peanuts $(\mathrm{kg} / \mathrm{ha})$ with a moisture content of $7 \%(\mathrm{wt} / \mathrm{wt})$.

y Means in columns followed by the same letters are not significantly different according to Duncan's multiple range test $(P=0.05)$.

${ }^{\mathrm{z}}$ Treated with captan $1.125 \mathrm{~g}+$ pentachloronitrobenzene (PCNB) $0.375 \mathrm{~g}+$ carboxin $0.25 \mathrm{~g}$ a.i. $/ \mathrm{kg}$ seed. 
cation of seed treatment fungicide and the change to an outside source of fungicidetreated seed. None of the soil-applied fungicides resulted in significant disease suppression in comparison to use of commercial seed treated with fungicide.

The fungicide test in 1995 was planted to commercial seed of NC 9 peanut that was treated with captan $1.125 \mathrm{~g}+$ PCNB $0.375 \mathrm{~g}+$ carboxin $0.25 \mathrm{~g}$ a.i. $/ \mathrm{kg}$. This seed was produced in fields believed to be free of collar rot in 1994. Disease incidence where metam was soil incorporated at 36 and $72 \mathrm{~kg} / \mathrm{ha}$ did not differ significantly from untreated plots. Likewise, disease incidence was not affected significantly by treatments with azoxystrobin at $0.28 \mathrm{~kg}$ a.i./ha, tebuconazole at $0.23 \mathrm{~kg}$ a.i./ha, iprodione at $1.12 \mathrm{~kg}$ a.i./ha, flutolanil at $1.12 \mathrm{~kg}$ a.i./ha, or fluazinam at $1.17 \mathrm{~kg}$ a.i./ha applied at planting and 60 DAP. Disease incidence at harvest averaged 7.0 plants/plot in the untreated check and levels in treated plots ranged from an average of 6.3 to 12 plants/plot. Yields averaged $2,653 \mathrm{~kg} / \mathrm{ha}$ in untreated plots and ranged from an average of 2,265 to $3,384 \mathrm{~kg} / \mathrm{ha}$ in treated plots. Azoxystrobin and fluazinam with yields of 3,249 and $3,384 \mathrm{~kg} / \mathrm{ha}$, respectively, were the only treatments that improved yield significantly. However, these yield increases were not associated with any visible suppression of collar rot or other diseases.

Peanut cultivars ranged from susceptible to resistant based on field trials in 1994 and 1995 (Table 5). Diseased plants were first detected in early June each year and continued to increase in number until harvest. Levels of disease at harvest in 1995 were generally lower than in 1994. The following groupings of cultivars were indicated based on disease incidence in 1994 and 1995: susceptible (NC 6, NC 7, NC 9, VA 93B, VA-C 92R, F-1025); moderately susceptible (Florunner, Agratech VC-1, NC-V11); and resistant (Georgia Browne,
Southern Runner, 79-X). Previous reports $(4,5,11)$ have identified peanut germplasm with resistance to collar rot. Results of the current study indicate that useful levels of resistance are commercially available in cultivars for combating this potentially destructive disease of peanut.

Although severe outbreaks of collar rot have been reported previously $(6,8)$, this is the first report of collar rot causing severe losses for peanut in Virginia. The localized outbreak of collar rot in Dinwiddie County, Virginia, in 1993 appears to be associated with the use of infested seed from diseased fields in 1992 and previous years, which is supported by the 1994 field study using infested seed. The incidence and severity of collar rot of peanut has been related to plant injury caused by high ambient air and soil temperatures (8) and wounding $(1,6)$. L. theobromae can act as a secondary pathogen by invading tissues affected by other, more aggressive pathogens $(9,13)$, but this did not appear to be a factor in the current study. In 1993, the growing season throughout Virginia and North Carolina was characterized as hot and dry at field sites exhibiting severe collar rot. Weather data collected in Suffolk, Virginia, showed daily maximum temperatures in June, July, and August 1993 were above $32^{\circ} \mathrm{C}$ a total of 11,25 , and 18 days, respectively. Maximum temperatures exceeded $32^{\circ} \mathrm{C}$ a total of 12, 23, and 4 days in 1994, and 1, 17, and 17 days in 1995 during June, July, and August, respectively. The rainfall deviation from the 66-year mean for the same period was $-24.4 \mathrm{~cm}$ in $1993,+0.36 \mathrm{~cm}$ in 1994 , and $-12 \mathrm{~cm}$ in 1995 . The relationship of these environmental factors to disease incidence each year remains unclear. Plants in fields with collar rot appeared to be neither wounded by cultivation nor damaged by other microorganisms, nematodes, or insects.

Isolates of L. theobromae from peanut in Dinwiddie County exhibited a characteris- tic appressed mycelial growth habit on PDA and greater aggressiveness in colonizing detached peanut stems in comparison to the less-aggressive isolates from other areas which had an aerial mycelial growth habit. More observations will be needed to determine the significance of this trait. The recommended changes of not saving seed from sites with collar rot and planting a less susceptible cultivar (NC-V 11 instead of NC 9) appears to have dramatically reduced the incidence of collar rot in Dinwiddie County, Virginia, from 1995 to 1998

\section{ACKNOWLEDGMENTS}

We thank N. Whitfield, B. Keeling, and S. Byrum for technical assistance; D. W. Gorbet for providing seed of the Florida breeding lines (F1025 and 79X); and J. Grichar for providing inshell samples of peanuts from Frio County and Yoakum, Texas.

\section{LITERATURE CITED}

1. Boyle, L. W. 1953. Heat canker: a primary phase of collar rot of peanut. Phytopathology 43:571-576.

2. Cu, R. M., and Phipps, P. M. 1993. Development of a pathogen growth response model for the Virginia peanut leaf spot advisory program. Phytopathology 83:195-201.

3. Garren, K. H., and Porter, D. M. 1970. Quiescent endocarpic floral communities in cured mature peanuts from Virginia and Puerto Rico. Phytopathology 60:1635-1638.

4. Gorbet, D. W., Coffelt, T. A., and van der Merwe, P. J. A. 1997. Disease- and insect-resistant cultivars. Pages 81-84 in: Compendium of Peanut Diseases. N. Kokalis-Burelle, D. M. Porter, R. Rodríguez-Kabána, D. H Smith, and P. Subrahmanyam, eds. American Phytopathological Society, St. Paul, MN.

5. Hammons, R. O. 1983. F334A-B-14 peanut germplasm. Crop Sci. 23:5.

6. Jacoway, T. H., and Owen, J. H. 1951. Stem rot of peanuts. Phytopathology 41:19.

7. Marasas, W. F. O., and Van Rensburg, S. J. 1986. Mycotoxicological investigations on maize and groundnuts from the endemic area of Mseleni joint disease in Kwazula (South Africa). S. Afr. Med. J. 69:369-374

8. McGuire, J. M., and Cooper, W. E. 1965. Interaction of heat injury and Diplodia

Table 5. Susceptibility of 12 peanut cultivars to Lasiodiplodia theobromae in a naturally infested field in Dinwiddie County, Virginia

\begin{tabular}{|c|c|c|c|c|c|c|}
\hline \multirow[b]{2}{*}{ Cultivar and type ${ }^{y}$} & \multicolumn{3}{|c|}{ Collar rotw } & \multicolumn{3}{|c|}{ Yield $^{x}$} \\
\hline & 1994 & 1995 & Mean & 1994 & 1995 & Mean \\
\hline NC $6(V)$ & $43.3 \mathrm{a}^{\mathrm{z}}$ & $24.3 \mathrm{a}$ & 33.8 & $2,883 \mathrm{~d}-\mathrm{f}$ & $2,728 \mathrm{c}$ & $2,805 \mathrm{de}$ \\
\hline NC 7 (V) & $47.3 \mathrm{a}$ & $24.8 \mathrm{a}$ & 36.0 & $2,282 \mathrm{fg}$ & $2,788 \mathrm{c}$ & $2,535 \mathrm{e}$ \\
\hline NC $9(\mathrm{~V})$ & $41.0 \mathrm{a}$ & $21.5 \mathrm{ab}$ & 31.3 & $2,515 \mathrm{fg}$ & $3,207 \mathrm{bc}$ & $2,861 \mathrm{de}$ \\
\hline NC-V $11(\mathrm{~V})$ & $27.5 \mathrm{~b}$ & $12.5 \mathrm{bc}$ & 20.0 & $3,583 \mathrm{~b}-\mathrm{d}$ & $3,177 \mathrm{bc}$ & $3,380 \mathrm{bc}$ \\
\hline VA-C 92R (V) & $42.5 \mathrm{a}$ & $26.0 \mathrm{a}$ & 34.3 & $2,613 \mathrm{e}-\mathrm{g}$ & $3,012 \mathrm{bc}$ & $2,813 \mathrm{de}$ \\
\hline VA $93 \mathrm{~B}(\mathrm{~V})$ & $45.5 \mathrm{a}$ & $19.3 \mathrm{ab}$ & 32.4 & $2,098 \mathrm{~g}$ & $2,743 \mathrm{c}$ & $2,420 \mathrm{e}$ \\
\hline AgraTech VC-1 (R) & $28.5 \mathrm{~b}$ & $19.0 \mathrm{ab}$ & 23.8 & $3,435 \mathrm{~b}-\mathrm{d}$ & $3,132 \mathrm{bc}$ & $3,284 \mathrm{~cd}$ \\
\hline Georgia Browne (R) & $3.0 \mathrm{c}$ & $4.5 \mathrm{c}$ & 3.8 & $4,000 \mathrm{a}-\mathrm{c}$ & $3,537 \mathrm{ab}$ & $3,768 \mathrm{ab}$ \\
\hline Southern Runner (R) & $2.5 \mathrm{c}$ & $3.8 \mathrm{c}$ & 3.1 & $3,288 \mathrm{c}-\mathrm{e}$ & $3,522 \mathrm{ab}$ & $3,405 \mathrm{bc}$ \\
\hline F-1025 (V) & $46.0 \mathrm{a}$ & $19.5 \mathrm{ab}$ & 32.8 & $2,540 \mathrm{fg}$ & $2,877 \mathrm{bc}$ & $2,709 \mathrm{e}$ \\
\hline $79-X(V)$ & $7.0 \mathrm{c}$ & $5.0 \mathrm{c}$ & 5.9 & $4,368 \mathrm{a}$ & $3,552 \mathrm{ab}$ & $3,902 \mathrm{a}$ \\
\hline Florunner (R) & $20.0 \mathrm{~b}$ & $7.5 \mathrm{c}$ & 13.8 & $4,036 \mathrm{ab}$ & $3,972 \mathrm{a}$ & $4,004 \mathrm{a}$ \\
\hline
\end{tabular}

${ }^{\mathrm{w}}$ Counts represent symptomatic and dead plants at harvest.

$x$ Yields are based on weight of peanuts $(\mathrm{kg} / \mathrm{ha})$ with moisture content of $7 \%(\mathrm{wt} / \mathrm{wt})$.

y Type: $\mathrm{V}=$ large-seeded Virginia peanut; $\mathrm{R}=$ small-seeded runner peanut. All seed were treated with captan $1.125 \mathrm{~g}+$ pentachloronitrobenzene $0.375 \mathrm{~g}+$ carboxin $0.25 \mathrm{~g}$ a.i. $/ \mathrm{kg}$.

${ }^{\mathrm{z}}$ Means in columns followed by the same letter(s) are not significantly different according to Duncan's multiple range test $(P=0.05)$. Analysis across years indicated statistical significance for year and variety in disease incidence and yield, as well as a significant year-by-variety interaction for disease incidence. 
gossypina and other etiological aspects of collar rot of peanuts. Phytopathology 55:231236.

9. Miller, J. H., and Harvey, H. W. 1932. Peanut wilt in Georgia. Phytopathology 22:371-383.

10. Porter, D. M., and Garren, K. H. 1968. An analysis of the endogeocarpic microflora of peanuts in Virginia. Trop. Sci. 10:100-106.

11. Porter, D. M., and Hammons, R. O. 1975.
Differences in plant and pod reaction of peanut diseases to infection of Diplodia gossypina. Peanut Sci. 2:23-25.

12. Porter, D. M., and Phipps, P. M. 1994. Diplodia collar rot of peanut: a recurrence. Proc. Am. Peanut Res. Educ. Soc. 26:58.

13. Porter, D. M., and Phipps, P. M. 1997. Diplodia collar rot. Pages 16-17 in: Compendium of Peanut Diseases. N. Kokalis-Burelle, D. M.
Porter, R. Rodríguez-Kabána, D. H. Smith, and P. Subrahmanyam, eds. American Phytopathological Society, St. Paul, MN

14. Ramakrishna, N., and Kolte, S. J. 1984. Collar rot of groundnut. Indian Phytopathol. 37:737.

15. Swann, C. W., ed. 1994. Peanut Production Guide. Va. Polytech. Inst. State Univ., Tidewater Agric. Res. Ext. Cent., Inf. Ser. 332. 